Developments in British Politics 


\section{Developments in British Politics}

Revised and updated

Henry Drucker General Editor

Patrick Dunleavy, Andrew Gamble, Gillian Peele Editors

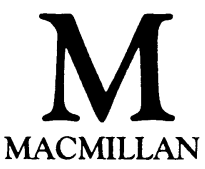


(C) Paul Arthur, Nick Bosanquet, Paul Byrne, Henry Drucker, Patrick Dunleavy, Andrew Gamble, Martin Holmes, Martin Kettle, Joni Lovenduski, Peter Nailor, Gillian Peele, Raymond Plant, R. A. W. Rhodes 1983.

All rights reserved. No reproduction, copy or transmission of this publication may be made without written permission.

No paragraph of this publication may be reproduced, copied or transmitted save with written permission or in accordance with the provisions of the Copyright Act 1956 (as amended).

Any person who does any unauthorised act in relation to this publication may be liable to criminal prosecution and civil claims for damages.

First edition 1983

Reprinted 1983

Revised edition 1984

Reprinted 1985

Published by

Higher and Further Education Division

MACMILLAN PUBLISHERS LTD

Houndmills, Basingstoke, Hampshire RG21 2XS

and London

Companies and representatives

throughout the world

\section{ACKNOWLEDGEMENTS}

The authors and publishers wish to thank the following who have kindly given permission for the use of copyright material:

Edward Arnold (Publishers) Ltd for figures by V. Duke and P. Edgell from International Journal of Urban and Regional Research.

Cambridge University Press for extracts from tables in the British Journal of Political Science, vols 7 (1977) and 12 (1982).

The Economist Newspaper Ltd for data from charts published in The Economist, 14 May 1979. 


\section{Contents}

Preface

List of Contributors

List of Abbreviations $\quad$ xiii

Glossary of Terms $\quad$ xvi

Introduction 1

Part One: The Constants

1 The Resurgence of Ideology Raymond Plant 7 End of Consensus 7

Resurgent Ideology 12

Conservative ideology $\quad 13$

Labour ideology 20

Alliance ideology $\quad 26$

2 Voting and the Electorate Patrick Dunleavy 30

Class De-alignment 31

Partisan De-alignment $\quad 38$

Growth of third-party voting $\quad 40$

Changes in political issues 41

Increase in electoral volatility $\quad 45$

Explaining De-alignment $\quad 46$

Social-base explanations $\quad 49$

Issue-change explanations $\quad 54$

The New Three-Party System and Politics in the 1980s 
3 The Parties and Parliament Henry Drucker 59 Westminster $\quad 60$

Dissent in the House $\quad 60$

New committee system $\quad 62$

Other changes in Parliament 64

The Parties $\quad 65$

Labour $\quad 66$

Social Democratic $\quad 71$

Conservative $\quad 74$

Liberal $\quad 76$

Scottish National $\quad 78$

Plaid Cymru $\quad 79$

The Party System $\quad 80$

4 Government at the Centre Gillian Peele 83

Thatcher's Ambiguous Record 84

Difficulties in Rolling Back the Public Sector $\quad 85$

Piecemeal Changes $\quad 87$

Parliamentary Control of the Civil Service $\quad 89$

More Leaks but no Open Government 91

Gradual Erosion of the 'Super-Departments' $\quad 92$

Abolition of the Civil Service Department 95

Reform of the Management and Personnel Office $\quad 97$

Management Information for Ministers (MINIS) 98

Specialist Advisers and 'Presidential' Government $\quad 100$

5 Beyond Whitehall Patrick Dunleavy and

R. A. W. Rhodes $\quad 106$

Who Administers Britain in the 1980s? 106

The Framework of Central-Local Relations 113

The interests of central departments 115

The interests of local government 118

The role of local government organisations at national level

The Development of Central-Local relations

since 1970

Bargaining 123

The corporatist pattern, 1974-9 124

Unilateral action and confrontation $\quad 126$

Prospects 
6 Economic Policy Andrew Gamble

Varieties of economic policy

The old political limits to economic policy

The challenges of the 1970s

The Policy-making Process

The role of government

The Treasury

Other ministries

Foreign Economic Policy

The EEC

The open world economy

Stabilisation Policy

Control of the money supply

Cash limits

Industrial Policy

Privatisation

Unemployment

The Agenda

7 Social Policy Nick Bosanquet

How is Social Policy Made?

Forces affecting Social Policy

Labour's Record

162

Conservative's Record

166

The Micro Climates of Social Policy

169

Social security

The National Health Service

170

Personal social services

172

Education

173

Housing

The Fiscal and Occupational Welfare States $\quad 175$

The Welfare State and the Individual

8 Foreign and Defence Policy Peter Nailor 179

Policy Machinery

Cabinet and cabinet committees 
The Domestic Context 185

Defence and public expenditure $\quad 185$

Nuclear arms $\quad 188$

The Foreign Context 190

The 'special relationship' 190

The European Community 191

European foreign policy 194

Part Two: New Worlds

9 The Police Martin Kettle 197

Challenges to the Consensus 197

Protecting the Police from Democracy 199

Reaction within the Parties $\quad 200$

Labour 201

Liberal and Social Democratic 203

Conservative 204

Failures of Policing 205

'Fire-brigade' policing 205

Loss of professional control 206

'Community policing' 206

Social Crises $\quad 207$

10 Trade Unions and Governments Martin Holmes 209

The End of 'Corporatism' 210

The Record since $1979 \quad 210$

No Formal Incomes Policy 213

Limited Scope of Legislation 215

Change in Union Leadership Styles $\quad 216$

Unemployment 218

Government's Handling of Disputes 219

Difficulties for Labour $\quad 220$

11 Two New Protest Groups: The Peace and Women's Movements Paul Byrne and Joni Lovenduski $\quad 222$

Origins and Aims 225

Organisation and Membership: The Network 227

Strategies $\quad 229$

Achievements and Prospects 231

Conclusion 235 
Contents ix

12 Northern Ireland Paul Arthur 238

Direct Rule $\quad 239$

'Ulsterisation' 241

Hunger Strikes $\quad 242$

Anglo-Irish Relations $\quad 244$

The 1982 Assembly $\quad 245$

The Lessons of Ulster $\quad 246$

... for the army 246

... for liberal democracy $\quad 247$

Part Three: The Political Science of British Politics

13 Analysing British Politics Patrick Dunleavy 253

Topics 254

Electoral behaviour $\quad 254$

Party competition $\quad 256$

The interest-group process 260

The mass media 264

$\begin{array}{ll}\text { Parliament } & 267\end{array}$

Cabinet government 270

The civil service 273

Quasi-governmental agencies 277

Local government and urban politics 281

The growth of government 284

The Major Theoretical Positions $\quad 288$

Reformulated pluralism 289

The new right $\quad 292$

Neo-pluralism 295

Marxist approaches $\quad 297$

Guide to Further Reading $\quad 300$

Bibliography $\quad 309$

Index $\quad 318$ 


\section{Preface}

This book is the result of unusually thorough discussions among the editors and with Steven Kennedy of Macmillan. I am grateful to them all for their patience and hard work. I am also grateful to the authors, who put up with my stream of late-night telephone calls and cheerfully accepted redrafting suggestions - and deadlines. Rodney Barker, John Bochel, John Bennett (who compiled the index), Paul Crompton, Richard Parry, Patrick Seyd and Adrian Sinfield were immensely helpful. Kathie Brown and Helen Ramm typed and retyped several chapters at impossible speeds.

Comments on this book and suggestions for future editions would be welcome.

The book was revised in the winter of 1983-4 to take account of the 1983 election and other recent events.

Department of Politics

Henry Drucker

University of Edinburgh

April 1984 


\section{List of Contributors}

Paul Arthur is Senior Lecturer in Politics at Ulster Polytechnic, and author of Government and Politics of Northern Ireland.

Nick Bosanquet is Lecturer in Economics at City University, and author of After the New Right.

Paul Byrne is Lecturer in Politics at Loughborough University, and author of articles on equal opportunities.

Henry Drucker is Senior Lecturer in Politics at Edinburgh University, and author of Doctrine and Ethos in the Labour Party.

Patrick Dunleavy is Lecturer in Government at the London School of Economics, and author of Urban Political Analysis.

Andrew Gamble is Reader in Politics at Sheffield University, and author of Britain in Deciine.

Martin Holmes is Lecturer in Politics at Lady Margaret Hall, Oxford, and author of Political Pressure and Economic Policy: British Government 1970-74.

Martin Kettle writes for The Sunday Times and is co-author of Uprising!

Joni Lovenduski is Senior Lecturer in Politics at Loughborough University, and author of Women in British Political Studies.

Peter Nailor is Professor of History and Dean of the Royal Naval College, and author of 'Defence Policy and Foreign Policy' in The Management of Britain's External Relations.

Gillian Peele is Fellow and Tutor in Politics at Lady Margaret Hall, Oxford, and co-author of The Government of the United Kingdom: Political Authority in a Changing Society.

Raymond Plant is Professor of Politics at Southampton University, and author of Political Philosophy and Social Welfare. 
xii List of Contributors

R. A. W. Rhodes is Lecturer in Government at Essex University, and author of Control and Power in Central/Local Relations. 


\section{List of Abbreviations}

$\begin{array}{ll}\text { AES } & \text { Alternative Economic Strategy } \\ \text { ASLEF } & \begin{array}{l}\text { Associated Society of Locomotive Engineers and } \\ \text { Firemen }\end{array} \\ \text { AUEW } & \text { Associated Union of Engineering Workers } \\ \text { BNOC } & \text { British National Oil Corporation } \\ \text { GAP } & \text { Common Agricultural Policy } \\ \text { GBI } & \text { Confederation of British Industry } \\ \text { GLPD } & \text { Campaign for Labour Party Democracy } \\ \text { CLPs } & \text { Constituency Labour Parties } \\ \text { CLV } & \text { Campaign for Labour Victory } \\ \text { CND } & \text { Campaign for Nuclear Disarmament } \\ \text { GPRS } & \text { Central Policy Review Staff } \\ \text { CSD } & \text { Civil Service Department } \\ \text { DAC } & \text { Direct Action Committee } \\ \text { DES } & \text { Department of Education and Science } \\ \text { DHSS } & \text { Department of Health and Social Security } \\ \text { DoE } & \text { Department of the Environment } \\ \text { DTp } & \text { Department of Transport } \\ \text { EEC } & \text { European Economic Community } \\ \text { EMS } & \text { European Monetary System } \\ \text { ERA } & \text { Equal Rights Amendment } \\ \text { FCO } & \text { Foreign and Commonwealth Office } \\ \text { GATT } & \text { General Agreement on Tariffs and Trade } \\ \text { GDP } & \text { Gross Domestic Product } \\ \text { GLC } & \text { Greater London Council } \\ \text { GNP } & \text { Gross National Product } \\ \text { GREA } & \text { Grant Related Expenditure Assessment } \\ \text { IEA } & \text { Institute of Economic Affairs } \\ \text { ILEA } & \text { Inner London Education Authority } \\ & \end{array}$


IMF International Monetary Fund

INLA Irish National Liberation Army

IRA Irish Republican Army

LCC Labour Co-ordinating Committee

MINIS Management Information System for Ministers

MoD Ministry of Defence

MORI Market \& Opinion Research International

MSC Manpower Services Commission

MTFS Medium Term Financial Strategy

NATO North Atlantic Treaty Organisation

NEB National Enterprise Board

NEC National Executive Committee

NHS National Health Service

NIO Northern Ireland Office

NIRG National Industrial Relations Court

NM Nautical Miles (6,076 feet)

NUPE National Union of Public Employees

NUR National Union of Railwaymen

OECD Organisation for Economic Co-operation and Development

OPEC Organisation of Petroleum Exporting Countries

PAC Public Accounts Committee

PG Plaid Cymru

PESG Public Expenditure Survey Committee

PLP Parliamentary Labour Party

PSBR Public Sector Borrowing Requirement

QGA Quasi-Governmental Agency

QUANGO Quasi Non-Governmental Organisation, or

Quasi National Governmental Organisation

RSL Revolutionary Socialist League

RUC Royal Ulster Constabulary

SAS Special Air Service

SDLP Social and Democratic Labour Party

SDP Social Democratic Party

SNP Scottish National Party

T \& GWU Transport and General Workers' Union

TUG Trades Union Congress

TULV Trade Unions for a Labour Victory

UDA Ulster Defence Association

UDR Ulster Defence Regiment 
List of Abbreviations $\quad \mathrm{xv}$

UWG Ulster Workers' Council

WLM Women's Liberation Movement 


\section{Glossary of Terms}

accountability Requirement for a public body, or a group of people who receive money from the public purse to account for how they behave. Conventionally many such groups, the police for example, have in effect been accountable to themselves. Many on the left now seek accountability to Parliament or local government.

adversary politics A version of two-party politics in which each party is extremist and each uses government to reverse wholesale the policies of its predecessors.

beer and sandwiches Description of Wilson government's (1964-70) attempts to solve industrial disputes by prolonged negotiations at No. 10 Downing Street involving 'beer and sandwiches' as refreshment.

block grant The unified central grant designed to equalise the resources and spending needs of individual local authorities (see GREA). It replaced the rate support grant, which had separate needs, resources and domestic elements. This last element was, in effect, a subsidy to householders and it continues as the 'domestic rate relief grant'.

Cabinet Secretariat The Prime Minister's office of about 100 civil servants, expanded under Wilson to include the Central Statistical Office and Heath to include the Central Policy Review Staff (the 'think tank').

capital expenditure expenditure on assets of some lasting value, usually more than one year. Most commonly it refers to money spent constructing schools, houses, roads, etc. Money for such projects is usually borrowed and the cost of repayment spread over a number of years. 
cash limits System of public spending calculations used from 1976-82 in which cash limits are imposed on particular items of public expenditure programmes.

cash planning The post-1981 method of planning of public expenditure which includes the whole of a programme, not just some items.

child benefit Cash payment for all children under 16 (or older if at school) usually paid to the mother. Introduced in 1977.

Child Poverty Action Group (CPAG) Pressure group of academics formed in the late 1960s to call attention to the failure of family allowances to keep pace with inflation.

child tax allowances An income-tax relief in respect of each child. Abolished in three stages from 1977 to 1979.

class A major line of division in society. Liberals define class in terms of occupations. Occupations are ordered into a lengthy status hierarchy, and then occupational classes are a simplified version of this hierarchy. Marxists define class in term of positions in a system of production; especially central are labour, ownership of capital and ability to determine one's own work.

class de-alignment A major weakening of the association between occupational class positions and patterns of voting.

clawback Adjustments to the block grant settlement of individual local authorities to reduce the total monies paid by central government in the course of the year.

coalition A government consisting of members of more than one party supported in the House of Commons by MPs of most constituent parties.

Common Agricultural Policy (CAP) The system of intervention prices for agricultural products which prevent prices falling below an agreed level, thus ensuring the protection of high-cost producers and encouraging the production of surpluses that cannot be sold.

community policing Idea that police officers should be known to and identified with the area in which they work and live. Many differing policies claim to be CP (see fire-brigade policing).

contingency funds Income which is not allocated to any 
specific purpose but reserved to cover unexpected calls on the funds of an authority.

core curriculum Proposal that central government should determine what teachers teach (the core) and examine. An attempt to return to 'basics'.

corporatism The view that government should seek agreement with the representatives of major interest groups over the management of the economy so as to secure their acquiescence in economic policy and to use the interest groups as instruments to carry out government policies.

current expenditure Constant, recurring expenditure on assets with a short life, usually less than one year. Most commonly it refers to money spent on salaries, goods and services and the interest on loans.

de-alignment Where one pattern of voter alignment (say, between class and a party) decays without being replaced by some new basis.

deterrence A doctrine about defence in a nuclear age which holds that safety and peace are best ensured by convincing the Soviet Union that any nuclear attack will be answered in kind - thus deterring it.

devolution Literally, the passing of power to subordinates. Usually, the creation of directly elected assemblies for one or more parts of the United Kingdom (e.g. Northern Ireland or Scotland) to control the domestic government of that part.

direct action Seeking to exert political influence directly, sometimes illegally, rather than through representative institutions.

dries and wets Terms derived from school-child slang commonly used (sometimes affectionately, often critically) to refer to the two factions of the Conservative Party. Dries are more concerned with the long-run effect of policy; wets with immediate pain and dislocation. 'Wet' is sometimes used derisively to refer to an MP who lacks courage or principle.

echelon advance An argument to the effect that if the rich become richer in a market economy, the poor, too, will become relatively richer. The increase in the standard of living will 'trickle down' to all sections of the community. 
European Monetary System (EMS) Established 13 March 1979. It comprises an exchange-rate structure which obliges members to keep their exchange rates within 2.25 per cent of agreed parities, an intervention mechanism and a system of credits. Britain declined to join in 1979.

factions A part of a political party which, remaining loyal to the whole, tries to move the party close to some principle or other. Factions tend to be long-lasting.

feminism Advocacy of women's rights in society on the basis of a belief in the equality of the sexes. May involve support for positive discrimination in favour of women in order to bring about equality more quickly.

fire-brigade policing Idea that police officers should be rushed to actual or potential areas of difficulty to apprehend suspects. Based on an assumption that police cannot effectively prevent crime. The concept involves the use of technology (two-way radios, computers, fast cars) rather than the confidence of ordinary citizens.

free collective bargaining Ability of unions and employers to bargain freely about wages and conditions of service without, or with minimal, government interference.

Grant Related Expenditure Assessment (GREA) The demand or need for services varies between local government areas because each area has different numbers of schoolchildren, old people, etc. Taking account of these variations, the government calculates how much money each authority needs to spend for each service in order to provide a common standard of service. The assessments for each service are totalled to give the GREA.

Gross Domestic Product (GDP) A standard measure of the value of all goods and services produced in a country (slightly narrower definition of wealth than GNP).

Gross National Product (GNP) A standard measure of the total output of goods and services produced in a given year valued at factor cost (i.e. excluding indirect taxes and subsidies).

Keynesianism A theory of economic management which dominated both main parties and the Treasury from the end of the Second World War to the mid-1970s. It bid government balance the economy, not the budget, and keep 
unemployment down by manipulating the level of effective demand by putting money in or taking it out of the economy.

International Monetary Fund (IMF) Founded in 1945. Industrial nations lend the Fund money which it lends back to them and other governments. Strict controls over a borrower government's economic and social policies are often imposed.

income maintenance Social security. An attempt to keep a person's or family's income above a certain level. It takes into account all state payments to an individual.

Manpower Services Commission (MSC) Established in 1974 by Heath government to run employment centres. Is a fast-growing QGA (which see). Performs employment and education tasks.

means-tested benefits State benefits to individuals paid out after taking account of the recipient's own income from all sources. The 'means' tested for many benefits varies with the 'benefit'.

Medium Term Financial Strategy (MTFS) Introduced in the 1980 budget. It sets targets for the growth of $\mathfrak{E M}_{3}$ (see money supply) and published projections for the public sector borrowing requirement (PSBR) (which also see).

monetarism Economic doctrine which asserts a clear relationship between the growth of the money stock and the rate of inflation in the medium term, and argues that the elimination of inflation by strict control of the money supply should be the major priority of policy.

money supply According to monetarism the key to the control of inflation is the control of the supply of money. The principal definitions are:

1. $\mathbf{M}_{1}$ - notes and coins in circulation with the public plus sterling current accounts held by the private sector.

2. $\mathfrak{E M}_{3}$ - notes and coins plus all sterling deposits held by UK residents in both public and private sectors.

3. $\mathbf{M}_{3}$ - equal to $\mathfrak{E M}_{3}$ plus all deposits held by $\mathrm{UK}$ residents in other currencies.

National Enterprise Board (NEB) Established in 1975 and is a QGA. Initial capital of $£ 1$ billion, it was intended as a state holding company which would establish state 
companies in the expanding sectors of the economy. It became part of the British Technology Group in 1980.

neo-liberalism The idea that the state has a very modest role to play in economic life. The state should concern itself with the institutional and procedural preconditions for successful production. It should not seek to direct investment in particular areas, or distort market decisions by inducing investment through tax concessions. The state should not be involved in questions of social justice and distribution.

1922 Committee Of back-bench Conservative MPs. First met in 1922, can exert considerable influence on the front bench.

North Atlantic Treaty Organisation (NATO) The chief Western alliance. Founded in 1949 at the peak of the Cold War it has fifteen member countries. Belgium, Canada, Denmark, France, Iceland, Italy, Luxembourg, the Netherlands, Norway, Portugal, the United Kingdom and the United States were members from the first. Greece and Turkey (both 1952) and the Federal German Republic (1955) were subsequently admitted. France and Iceland (which has no military forces) do not play a full role.

Organisation for Economic Co-operation and Development (OECD) The industrialised nations of the West: Australia, Austria, Belgium, Canada, Denmark, the German Federal Republic, Finland, France, Greece, Iceland, Ireland, Italy, Japan, Luxembourg, the Netherlands, New Zealand, Norway, Portugal, Spain, Sweden, Switzerland, Turkey, the United Kingdom and the United States. Acts to promote the economic and social well-being of the members and their citizens and to harmonise their relations with the developing countries.

Organisation of Petroleum Exporting Countries (OPEC) Founded in 1960 by countries largely dependent on the export of oil to earn foreign exchange. Tries to regulate the market for petroleum in their interest. Members: Algeria, Ecuador, Gabon, Indonesia, Iran, Iraq, Kuwait, Libya, Nigeria, Qatar, Saudi Arabia, the United Arab Emirates, Venezuela. Britain, though a net petroleum-exporting country, is not a member. 
partisan de-alignment A weakening association between voters' choice of party and their views on major political issues.

party government As opposed to pressure group, civil service domination or direct government. The practice of parties, victorious at elections, trying to govern without support in the House of Commons from other parties, in line with their election promises.

peace movement A collection of mainly local groups, committed to unilateral disarmament, with the Campaign for Nuclear Disarmament (CND) acting as a national umbrella organisation.

permeation The view of political change held by leading members of the Fabian Society. Political change was to be introduced by the permeation of socialist ideas among the elite.

Polaris A submarine which carries sixteen nuclear weaponcarrying missiles; each missile has a range of 2,500 nautical miles and carries three warheads. Britain's Polaris submarines were commissioned in 1967-9.

privatisation (1) The sale of public assets, e.g. the share of public corporations like Amersham or British Telecom. (2) The contracting out of certain public services to private companies. (3) The setting up of private companies to compete with state corporations.

public sector borrowing requirement (PSBR) The difference between expenditure and revenue for the whole public sector. A main aim of monetarist (which see) policies was to reduce this figure.

quasi-governmental agency (QGA) A public body whose controlling board is appointed by the government to carry out a single function. Often known as a QUANGO (which name is confusing).

rates The local property tax levied on the value of a property and paid by the occupier of that property. Different classes of property (domestic and commercial) are valued differently, and some (agricultural land and buildings) not at all.

referendum A ballot of citizens on an issue of public policy. In Britain referendums are usually not binding. For 
example, one was held with respect to Britain's membership of the EEC in 1975.

revenue expenditure See current expenditure.

revisionism The term used for socialist and social democratic critiques of Marx. It was first used to describe Edmund Bernstein's critique of Marxism, Evolutionary Socialism. By the 1950s it had come to be used to identify the Gaitskellite wing of the Labour Party who were anxious to move the party away from class-based politics and from large-scale commitments to nationalisation.

Royal Commission on Criminal Procedure Inquiry set up by the Callaghan government under the chairmanship of Sir Cyril Philips to examine police powers in the criminal process up to the start of a trial. Reported in 1981. The basis of legislation in 1983.

Social Contract Agreement between unions and the Labour government of 1974-9 that in return for union wage restraint the government would legislate to extend tradeunion powers.

social limits to growth The view associated with Fred Hirsch that certain kinds of goods are inherently scarce because the more widely they are distributed, the less value they have. Power and education are examples.

social protest movement A group which advocates fundamental changes in public policy and/or political institutions, but does not seek political office.

Special Air Service (SAS) Created during Second World War. Brought into Ulster by the government in 1976 to help defeat terrorists in the border areas. Its undercover operations raised tensions among Ulster Catholics.

Special Patrol Group Elite crime-busting squad set up by Scotland Yard in 1965 with its own separate structure answerable directly to the Commissioner. Much copied by other British forces and hugely demonologised. The SPG was involved in the killing of Blair Peach.

'special relationship' Between the United States and the United Kingdom. Supposed to link the two Englishspeaking powers closer to each other than to third parties. Unheard of in the United States!

statism The view that the state has a duty to intervene in 
and manage the economy with the intention of securing a particular set of social and economic priorities.

supplementary benefit Payments by the state to heads of households who do not have full-time work and whose 'needs' exceed their income.

Think tank (CPRS) was a small body of advisors established in 1970 by the Heath Government to aid long-term planning and policy development. Its first head was Lord Rothschild and it consisted of individuals recruited from outside the civil service. After Lord Rothschild's departure its functions became unclear and it was abolished in 1983.

trading services Those local authority services for which a charge is made to the consumer. They are expected to generate enough revenue to meet their outgoings and include passenger transport, cemeteries and crematoria, harbours, docks and piers, restaurants, markets and slaughter houses, airports. Council-house rents are the main source of such revenues but differ from the foregoing services in that the income can only be credited to the housing revenue account and not to the general rate fund.

Trident Submarine system planned to replace Polaris. Each carries sixteen missiles and each missile carries up to fourteen warheads. The missiles have a range of 6,000 nautical miles.

tripartite talks Discussions between the TUC, CBI and government aimed at finding agreement on a voluntary incomes policy. They were most fashionable under the Heath government.

two-party system Electoral and parliamentary dominance by two large parties each of which reasonably expects to form a government without help from any minor party after each election. Apparent in the United Kingdom from 1945 to 1974 and important features of it are still present.

Ulster Defence Association The largest Protestant paramilitary organisation. Formed in September 1971, at its peak it probably had 40,000 members. By 1982 it probably had no more than 12,000 . In recent years its leadership has been moving towards Ulster independence.

Ulster Defence Regiment (UDR) Locally raised, and a largely part-time force, it began operations in April 1970. It 
is under the control of the British army and is open to all religions, but perhaps no more than 3 per cent of its membership is Catholic. It serves as a back-up force for the British army.

unilateralism Action, such as disposing of nuclear arms, which affects or is binding upon only one party or country. volatility The frequency and extent to which people change their votes or views on issues. Has been increasing in recent years.

volume targets The desired level of public expenditure expressed in constant-price terms. For local authorities the base year for 1981-2 targets was the 1978-9 actual expenditure repriced at November 1980 prices.

'winter of discontent' Wave of strikes in the public and private sectors in the winter of 1978-9 which destroyed the Callaghan government's 5 per cent pay policy.

Zimbabwe Formerly Rhodesia. Country in southern Africa whose white rulers, led by Ian Smith, unilaterally declared independence from Britain in 1965. Granted formal independence after prolonged war in 1979. 